\title{
Developing a novel Grey integrated multi-criteria approach for enhancing the supplier selection procedure: A real-world case of Textile Company
}

\author{
Rim Bakhat ${ }^{\mathrm{a}^{*}}$ and Mohammed Rajaa ${ }^{\mathrm{b}}$
}

${ }^{a}$ PhD Student, Abdel Malek Essadi University Tangier, Morocco

${ }^{b}$ Prof Dr Abdel Maled Essadi University, Faculty of economics and management sciences, Tétouan, Morocco

\begin{tabular}{l}
\hline C H R O N I C L E \\
\hline Article history: \\
Received March 7, 2019 \\
Received in revised format: \\
March 29, 2019 \\
Accepted April 1, 2019 \\
Available online \\
April 2, 2019 \\
\hline Keywords: \\
Supplier selection \\
G-AHP \\
WASPAS-G \\
MCDM
\end{tabular}
\begin{abstract}
A B S T R A C T
Supplier selection is one of the most essential activities in purchase management and plays a crucial role in the production phase. Supplier selection as a vital step of supply chain management is a multi-criteria decision-making issue. For any organization, the process of selecting the best supplier holds variable multilayered complications involving quantitative and qualitative criteria. This paper tackles the supplier selection problem in a Turkish Textile Company. The present study carries out a novel grey integrated multi-criteria approach for enhancing the supplier procedure within Textile Company with the help of the grey analytical hierarchy process G-AHP model for weighting the set of criteria, and the grey weighted aggregated sum product assessment WASPAS-G model for prioritizing the suppliers. The study starts with reviewing the previous works of multi-criteria decision-making MCDM methods and the list of existing criteria evaluation in supplier selection. Then, the range of criteria is selected based on the company requirements and the experts' interview. In the case study, the consistency rate of the models is tested in order to verify the quality of experts' judgments. The final results affirm that Grey integrated approach could be efficient and far more precise than the existing models for overcoming the supplier selection and evaluation obstacles in the supply chain management.
\end{abstract}

C 2018 by the authors; licensee Growing Science, Canada.

\section{Introduction}

During the last decade, many organizations in the industrial area have faced a sharp competition due to the fact of globalization which has pushed them to choose the outsourcing strategy as a right solution to produce products at minimal cost. This strategy has participated in controlling the costs of sourced raw materials and products that are very often qualified to cover organization requirements and increase at the same time their competitiveness in the market (Steven et al., 2014). Currently, many organizations heavily rely on outsourcing trends and have become more dependent on suppliers to achieve their business tasks. Consequently, outsourcing in developing countries may have entailed some certain side-effects, e.g. the procedure of treatment with the suppliers has become more complex and the supply chain foundations turned into fragments, which would undoubtedly impact on the products quality and the organization's performance (Steven et al., 2014). In fact, the supply chain and

* Corresponding author.

E-mail address: rbakhat@uae.ac.ma (R. Bakhat)

(C) 2019 by the authors; licensee Growing Science, Canada doi: $10.5267 /$ j.dsl.2019.4.001 
suppliers performance have become more serious for the organizations' goals achievement (Handfield et al., 2002). In other words, the recent business world is no longer seen as a competition among organizations but among the organizations' suppliers as well (Lambert \& Cooper 2000; Li et al., 2006; Bai \& Sarkis 2014; Amid et al., 2009). In addition, supplier selection and evaluation process is considered as a crucial success factor and serious strategic decision-making issue that participate in enforcing the partnerships in supply chain (Chen \& Paulraj, 2004). In other words, the supplier selection is considered as one of the most valuable problems for building a cornerstone in the supply chain management. The core objective of the supplier selection procedure is to reduce the risks and increase the value of relationships between organizations and suppliers as maximum as possible (Monczka et al., 1998). Recently, the most common goal of supplier selection is to designate the most appropriate supplier with the highest capabilities in delivering high-quality products and/or services at an affordable cost (Beşkese \& Şakra, 2010). In essential, previous works have developed various models for supplier selection and evaluation process with regard to decision-making techniques (Boer et al., 1998; Lee et al., 2001).

However, these adopted techniques such as MCDM techniques are not sufficient and able to solve the complexity of nowadays organizations' purchasing strategies (Boer et al., 1998). As a consequence, the current supply chain has become far complex and ramified where disturbance can come at any time (Christopher, 2004). Previous researches have developed numerous studies in this domain that generally involve the adoption of the practical approaches and the application of a broader range of methodologies especially mathematical analytical (MA) models. Therefore, various MCDM methods have been formulated in order to re-arrange and support difficult decisions such as supplier selection (Wu et al., 2010). The procedure for selecting and evaluating the most potential supplier encompasses a broader set of external and internal influencing indicators (Kumar et al., 2014), this range takes the qualitative and quantitative selection and evaluation criteria into account (Sarkis \& Talluri 2002), and holds out the variety of suppliers crosswise the supply chain (Bai \& Sarkis 2010). Nowadays, selecting the most appropriate supplier not only relies on investigating some price list but, also it also relies on a broader range of criteria such as quality, delivery, technological capability, technical support. Then, the organization's internal or external aspects could be weighted based on its requirements, priorities, and long-term economic strategies. The designation of the criteria and the function of each defined criterion change from field to field. For this reason, organizations from different areas ought to embrace a strategic approach to facilitate the management of suppliers' partnership and prevent "one-size-fitsall" approach for supplier partnership management (Gurler AGI, 2007; Yilmaz O et al., 2011; Sagar MK et al., 2012).

Adopting a managerial approach that relies on more than one supplier can reduce the risk of production or service disruptions. The key challenge herein is not only to identify the main role of the supplier, but rather develop new approaches and methodologies to highlight supplier selections problems and solve the significant complexity within the supply chain. The vagueness and uncertainty are the certain sides of information specifically when the assessment procedure is handled by human judgment (Ghorabee et al., 2017). According to the tackled theory, as presented in section 2, the prior studies have mostly focused on the Fuzzy set theory or Hybrid theory and few limited works have taken Grey set theory into consideration in solving supplier section and evaluation problems. The core contribution of the present study is to present a novel grey integrated approach, which consists of G-AHP to identify the weightiness of criteria and WASPAS-G to classify the suppliers, to handle uncertainty in the supplier selection and evaluation procedure. Afterwards, a case study of Turkish Textile Company will be investigated to verify the constructed model and to show the feasibility of the suggested techniques. The present paper is structured as follows: Section 2 highlights the prior works on MCDM methods and mathematical models used for overcoming the obstacles faced throughout the process of selecting the convenient supplier. Section 3 underpins the development of a novel integrated model with the use of G-AHP and WASPAS-G techniques. Section 4 comprises the application and the verification of the constructed model in a case study of Textile Company. Section 5 presents the final results and 
discussions for future researches. Section 5 also underlines the practicability and reliability of the new approach. Section 6 concludes the present work and proposes some valuable recommendations for future researches.

\section{Literature review}

In this section, the literature review is mainly divided into two sections. First, the set of criteria defined by previous works will be reviewed. Then, the appropriate criteria in weighing and prioritizing suppliers for the present work will be outlined. Second, some of the MCDM methods and other mathematical models investigated in previous works for overcoming the problem of supplier selection will be also highlighted.

\subsection{Supplier evaluation criteria assignment}

Successfully performing the supplier selection strategy in the supply chain, researchers have to take into consideration a wide range of criteria. In other words, the selection of accurate criteria represents a basic step in the decision-making procedure for assessing and prioritizing suppliers (Buyukozkan \& Cifci 2011). Weber et al. (1991) stated that the price is an essential indicator in decision making for evaluating end selecting the right supplier. Ho et al. (2010) declared that the basic set of criteria for selecting the resilient supplier entails price, quality, and delivery. While Chang et al. (2011) conducted a research that encompasses ten essential criteria which paid, later on, attention by numerous researchers from different fields of study. This set of criteria is as follows: 'quality, delivery reliability, lead time, cost, capacity, flexibility, technology capability, environmental control, service level, and reduction on demand'. However, this range of criteria can vary from one study to another. In the present work, the range of criteria will be selected and designated based on the supplier selection strategy requirements within the textile industry. The present study range of criteria encompasses quality, cost, technological capability, technical support, delivery, flexibility, supplier reputation, and discount opportunities.

\section{Table 1}

Summary of supplier selection criteria in prior researches

\begin{tabular}{|c|c|}
\hline Authors & Associated criteria \\
\hline Sen et al., 2009 & Quality, Socio-economic, and technology \\
\hline Luo et al., 2009 & Resource and financial quality, and management \\
\hline Kahraman et al., 2010 & Service and product performance, and cost \\
\hline Guneri et al., 2011 & Quality, delivery, supplier relationship, problem-solving capability, and cost \\
\hline Razaei et al., 2013 & Supplier relationship, and exchange elements \\
\hline Arikan et al., 2013 & Quality, price, delivery, and capacity \\
\hline Kumar Kar et al., 2014 & Price, technology, financial management, delivery, E-transaction ability, and service product quality \\
\hline Deng et al., 2014 & Quality, risk factors, supplier's benefits, and service performance \\
\hline Ulutas et al., 2016 & $\begin{array}{l}\text { Cost, financial position, delivery, flexibility, quality, technology, compliance with sectorial price, } \\
\text { reputation, and communication issues }\end{array}$ \\
\hline The present paper & $\begin{array}{l}\text { Quality, cost, technological capability, technical support, delivery, flexibility, supplier reputation, and } \\
\text { discount opportunities }\end{array}$ \\
\hline
\end{tabular}

\subsection{Review of prior works based on MCDM techniques in supplier selection}

During the last two decades, multi-criteria decision-making MCDM methods have become one of the most valuable approaches applied in the different research areas (Jato-Espino et al., 2014). During this period, numerous models have been developed and reformulated in order to overcome the complexity discovered through the process of the supplier selection but, the majority of researchers have mostly focused on decision-making methods, with complex mathematical models, to resolve the supplier selection problem. In literature, however, various studies have tackled and proposed different techniques in a variety of ways for overcoming the issue of complexity in supplier selections. Table 1 highlights and summarizes the most important methods adopted by several researchers for supplier selection and evaluation, respectively. 


\section{Table 2}

\section{Review of prior researches in applying variable models for supplier selection}

\begin{tabular}{|c|c|c|}
\hline Authors & Methods & Article Abstract \\
\hline Önüt et al., 2009 & $\begin{array}{l}\text { Fuzzy set, MCDM, and TOPSIS } \\
\text { ANP }\end{array}$ & $\begin{array}{l}\text { Proposed a supplier selection approach that relies on the application of TOPSIS and ANP to overcome } \\
\text { the obstacle of selecting the right supplier in the telecommunication industry. }\end{array}$ \\
\hline Amid et al., 2009 & Fuzzy MCDM & $\begin{array}{l}\text { Presented a weighted fuzzy multi-objective approach to support the supplier selection and evaluation } \\
\text { under fuzzy environment. }\end{array}$ \\
\hline Wang et al., 2009 & $\begin{array}{l}\text { MCDM, Fuzzy TOPSIS, and Fuzzy } \\
\text { FAHP }\end{array}$ & $\begin{array}{l}\text { Developed an approach that combines both Fuzzy TOPSIS and Fuzzy AHP to evaluate and select the } \\
\text { right. }\end{array}$ \\
\hline Boran et al., 2009 & $\begin{array}{l}\text { MCDM, TOPSIS, and Fuzzy set } \\
\text { theory }\end{array}$ & $\begin{array}{l}\text { Presented an intuitionistic fuzzy approach with the use of TOPSIS technique to support the selection of } \\
\text { the right supplier. }\end{array}$ \\
\hline Sanayei et al., 2010 & Fuzzy set, and VIKOR & $\begin{array}{l}\text { Developed a hierarchy MCDM approach that relies on Fuzzy VIKOR technique as a convenient model } \\
\text { to deal with complexity in supplier selection strategy. }\end{array}$ \\
\hline $\begin{array}{l}\text { Shemshadi et al., } \\
2011\end{array}$ & $\begin{array}{l}\text { Fuzzy logic, VIKOR, Entropy } \\
\text { measure, and MCDM. }\end{array}$ & $\begin{array}{l}\text { Developed a fuzzy VIKOR method in order to overcome the MCDM criteria conflicts problems. } \\
\text { Shannon entropy is used to fix the subjectivity of weights of judgements. }\end{array}$ \\
\hline Deng et al., 2011 & $\begin{array}{l}\text { MCDM, Dempster-Shafer theory, } \\
\text { Fuzzy sets theory and TOPSIS }\end{array}$ & $\begin{array}{l}\text { Presented a combination of FST and DST as an ideal and flexible solution for an uncertain environment. } \\
\text { TOPSIS is then proposed to solve the problem in supplier selection. }\end{array}$ \\
\hline Lin et al., 2011 & $\begin{array}{l}\text { Enterprise resource planning (ERP), } \\
\text { ANP, TOPSIS, and Linear } \\
\text { programming (LP). }\end{array}$ & $\begin{array}{l}\text { Applied ERP and LP methods in order to specify the strength and weakness in the supplier selection } \\
\text { and evaluation procedure. TOPSIS and ANP are employed to compute the weights and rank the } \\
\text { suppliers. }\end{array}$ \\
\hline $\begin{array}{l}\text { Buyukozkan et al., } \\
2012\end{array}$ & $\begin{array}{l}\text { Fuzzy ANP, DEMATEL, and } \\
\text { TOPSIS. }\end{array}$ & $\begin{array}{l}\text { Integrated a new hybrid fuzzy MCDM approach based on the use of DEMATEL, ANP and TOPSIS } \\
\text { are then proposed to evaluate the green suppliers. }\end{array}$ \\
\hline Haldar et al., 2012 & $\begin{array}{l}\text { AHP, TOPSIS, subjective factor } \\
\text { measures (SFM), and objective } \\
\text { factor measure (OFM). }\end{array}$ & $\begin{array}{l}\text { Presented a hybrid approach that incorporates MCDM techniques together to help decision makers to } \\
\text { designate the right supplier. AHP-QFD is used to reveal the critical criteria. Afterwards, SFM and OFM } \\
\text { are used to define the factor affecting supplier selection. }\end{array}$ \\
\hline Nilesh et al., 2012 & Fuzzy set theory AHP, and ANP. & $\begin{array}{l}\text { Proposed a detailed review of supplier selection and projected the practicability of MCDM techniques } \\
\text { for futures researcher and studied the feasibility of these techniques in the current published literature. }\end{array}$ \\
\hline $\begin{array}{l}\text { Khodadadzadeh et al., } \\
2013\end{array}$ & $\begin{array}{l}\text { MCDM, Data development analysis } \\
\text { (DEA), TOPSIS, and AHP }\end{array}$ & $\begin{array}{l}\text { Proposed a survey of employing different form of MCDM techniques for supplier selection and } \\
\text { evaluation such as DEA, TOPSIS, and AHP. }\end{array}$ \\
\hline Ghorbani et al., 2013 & Fuzzy TOPSIS, and Kano model. & $\begin{array}{l}\text { Formulated a new approach that integrates Fuzzy TOPSIS and Kano MODEL. This study has taken the } \\
\text { ambiguity of people judgement into consideration to solve the issue of supplier selection. }\end{array}$ \\
\hline Dursun et al., 2013 & $\begin{array}{l}\text { Quality function deployment (QFD), } \\
\text { MCDM, and Fuzzy weighted } \\
\text { average (FWA). }\end{array}$ & $\begin{array}{l}\text { Developed a fuzzy model that uses QFD for the supplier selection process. The FWA method is utilized } \\
\text { to turn the imprecise information into linguistic variables. }\end{array}$ \\
\hline Memon et al., 2015 & $\begin{array}{l}\text { Grey systems theory, and } \\
\text { uncertainty theory. }\end{array}$ & $\begin{array}{l}\text { Presented a framework of Combined grey systems theory and uncertainty theory for minimizing the } \\
\text { risk of purchase quantity associated with suppliers. }\end{array}$ \\
\hline Ertugrul et al., 2015 & $\begin{array}{l}\text { Fuzzy set theory (FST) MCDM, and } \\
\text { QFD }\end{array}$ & $\begin{array}{l}\text { Proposed a framework proposed to use a combination of ordered weighted averaging (OWA) and Fuzzy } \\
\text { set theory. }\end{array}$ \\
\hline Awasthi et al., 2016 & $\begin{array}{l}\text { Fuzzy set theory (FST) NGT, and } \\
\text { VIKOR. }\end{array}$ & $\begin{array}{l}\text { Formulated Fuzzy NGT to evaluate the green supplier and Fuzzy VIKOR is then applied to rank and } \\
\text { propose the most appropriate green supplier. }\end{array}$ \\
\hline $\begin{array}{l}\text { Nallusamy et al., } \\
2016\end{array}$ & Fuzzy AHP, AN, and FL & $\begin{array}{l}\text { Proposed the linear weighting techniques to solve the complexity problem faced throughout the process } \\
\text { the supplier selection. }\end{array}$ \\
\hline $\begin{array}{l}\text { Rezaeisaray et al., } \\
2016\end{array}$ & $\begin{array}{l}\text { MCDM, DEMATEL, FANP, and } \\
\text { DEA }\end{array}$ & $\begin{array}{l}\text { Proposed a novel hybrid model to select and evaluate the most resilient supplier based on the utilization } \\
\text { of DEMATEL for structuring the criteria. FANP and DEA are used to weight the criteria. }\end{array}$ \\
\hline Chen et al., 2016 & Fuzzy AHP, and TOPSIS & $\begin{array}{l}\text { Presented an appropriate model for green supplier selection comprising environmental and economic } \\
\text { criteria in supplier selection procedure. }\end{array}$ \\
\hline Yazdani et al., 2016 & $\begin{array}{l}\text { MCDM, SWARA, QFD, and } \\
\text { WASPAS }\end{array}$ & $\begin{array}{l}\text { Presented an integrated frame for formulating an effective supplier selection approach in the supply } \\
\text { chain with the use of SWARA, QFD and WASPAS. }\end{array}$ \\
\hline J Rezaei et al., 2016 & MCDM, and BWM & $\begin{array}{l}\text { Applied a methodology for selecting the most potential supplier within a food supply chain background } \\
\text { with the use of the best and worst method. }\end{array}$ \\
\hline Wan et al., 2017 & $\begin{array}{l}\text { MCDM, II IT-ELECTRE II, and } \\
\text { TL-ANP }\end{array}$ & $\begin{array}{l}\text { Investigated MCDM problems with regard to two-level criteria and Presented a new hybrid approach } \\
\text { combining TL-ANP and IT-ELECTRE II to select the most appropriate supplier in the supply chain. }\end{array}$ \\
\hline Gupta et al., 2017 & BWM, and Fuzzy TOPSIS & $\begin{array}{l}\text { Presented a methodology that relies on the Fuzzy TOPSIS and BWM to rank and weight the criteria of } \\
\text { green suppliers in the supply chain. Sensitivity analysis is also tackled to check the strength of the } \\
\text { constructed framework. }\end{array}$ \\
\hline Hamdan et al., 2017 & $\begin{array}{l}\text { MCDM, multi-objective } \\
\text { optimization approach, AHP, and } \\
\text { TOPSIS. }\end{array}$ & $\begin{array}{l}\text { Presented a multi-objective optimization approach that combines fuzzy AHP and Fuzzy TOPSIS to opt } \\
\text { the most potential supplier. }\end{array}$ \\
\hline Parkouhi et al., 2017 & Fuzzy ANP and Grey VIKOR. & $\begin{array}{l}\text { Used Fuzzy ANP to determine the potential supplier and Grey VIKOR were applied to specify the level } \\
\text { of importance of the resilient supplier. }\end{array}$ \\
\hline $\begin{array}{l}\text { Buyukozkan et al., } \\
2017\end{array}$ & IFAD and IF-AHP. & $\begin{array}{l}\text { Integrated an approach used to overcome the vagueness and handle the ambiguity of the decision } \\
\text { process in supplier selection and evaluation. }\end{array}$ \\
\hline Bakeshlou et al., 2017 & $\begin{array}{l}\text { MCDM, Fuzzy ANP, and Fuzzy } \\
\text { DEMATEL, MOLP }\end{array}$ & $\begin{array}{l}\text { Presented an approach that relies on Fuzzy ANP and DEMATEL to perceive the interrelation between } \\
\text { criteria for green suppliers. }\end{array}$ \\
\hline Yazdani et al., 2017 & $\begin{array}{l}\text { DEMATEL, quality function } \\
\text { deployment (QFD), and COPRAS. }\end{array}$ & $\begin{array}{l}\text { Addressed an approach that combines QFD with DEMATEL to construct a fundamental relationship } \\
\text { matrix to determine the nature of the relationship between green supplier selection criteria. }\end{array}$ \\
\hline Goh et al., 2018 & $\begin{array}{l}\text { MCDM, Fuzzy AHP, and Fuzzy } \\
\text { TOPSIS. }\end{array}$ & $\begin{array}{l}\text { Formulated AHP and TOPSIS model with the help of Fuzzy set theory to support the selection of } \\
\text { healthcare suppliers. }\end{array}$ \\
\hline Jiang et al., 2018 & $\begin{array}{l}\text { MCDM, DEMATEL, ANP, and } \\
\text { Grey DANP. }\end{array}$ & $\begin{array}{l}\text { Developed a grey-DANP model to decrease the problem coming from the pairwise comparison in } \\
\text { supplier selection criteria. }\end{array}$ \\
\hline $\begin{array}{l}\text { Yousaf Ali et al., } \\
2018\end{array}$ & MCDM, ANP, and TOPSIS. & $\begin{array}{l}\text { Used an approach technically applied to assign variable range of criteria for supplier selection in the oil } \\
\text { refinery. }\end{array}$ \\
\hline Quan et al., 2018 & $\begin{array}{l}\text { MCDM, MULTIMOORA, and } \\
\text { LINMAP. }\end{array}$ & $\begin{array}{l}\text { Proposed the development of hybrid MCDM approach to objectively evaluate the criteria for green } \\
\text { supplier selection and handle the uncertainty in data. }\end{array}$ \\
\hline Liu et al., 2018 & $\begin{array}{l}\text { Game theory, DEMATEL, MCDM, } \\
\text { and ANP }\end{array}$ & $\begin{array}{l}\text { Presented a combination of different methods used to limit the fuzziness and ambiguity in supplier } \\
\text { selection process. }\end{array}$ \\
\hline Haeri et al., 2019 & $\begin{array}{l}\text { Grey relational analysis, BWM, and } \\
\text { Fuzzy grey cognitive maps }\end{array}$ & $\begin{array}{l}\text { Proposed a grey-based model for choosing the most convenient green supplier with the help of Fuzzy } \\
\text { techniques. }\end{array}$ \\
\hline Mohamed et al., 2019 & $\begin{array}{l}\text { Fuzzy FMOO, Fuzzy AHP, and } \\
\text { Fuzzy TOPSIS. }\end{array}$ & $\begin{array}{l}\text { Presented a hybrid MCDM to resolve the issue of multiple uncertainties in supplier selection procedure } \\
\text { by taken the economic, environmental and social criteria into consideration. }\end{array}$ \\
\hline $\begin{array}{l}\text { Deshmukh et al., } \\
2019\end{array}$ & MCDM and Fuzzy FAHP. & Developed a Fuzzy FAHP model to select and evaluate the most appropriate green supplier. \\
\hline Lieu et al., 2019 & MCDM, BWM, and AQM & $\begin{array}{l}\text { Adopted the best worst method and alternative queuing method with MCDM technique to solve rank } \\
\text { the supplier. }\end{array}$ \\
\hline Bai et al., 2019 & Grey- BWM, and Grey-TODIM & Proposed Grey approach to determine social sustainability attribute weights and ranking the suppliers. \\
\hline
\end{tabular}


In theory, only a few researchers have tackled the Grey systems theory to support MCDM techniques in supplier selection. Therefore, it is noticed that during the last decades the Grey systems theory has been recognized by numerous researchers as a successful approach due to the results have been harvested in several research fields such as economy (Julong, 1984), industry (Biao, 1986) management (Julong, 1986c), etc.

The core objective of the present study is to adopt a Grey systems theory to support MCDM techniques and overcome the complexity highlighted during the process of selecting the most resilient supplier. Consequently, the main role of the developed Grey integrated model herein is to handle the vagueness revealed in the supplier selection procedure. The Grey systems theory used within this study holds variable advantages (e.g. Li et al., 2007; Tseng, 2009; Bai et al., 2010; Saeedpoor et al., 2012; Dou et al., 2014; Memon et al., 2015; Xia et al., 2015):

- the grey systems theory provides reasonable results employing a moderate amount of data compared with other statistical modelling methods and techniques;

- it is considered as one of the improved theories in terms of exact and completed information;

- it is a solid theory towards the noise and shortage of information modelling;

- the theoretical contribution has proved that a grey-based method can accomplish remarkable performance features;

- the grey systems theory offers 'no parametric, a relatively resilient, distribution assumptions, and the best way to turn fuzziness into a problem';

- it is better than fuzzy set theory in term of the fuzziness conditions;

- it does not require any kind of fuzzy robust membership tasks;

- the advantages of this method over fuzzy set theory are that it is developed in case of tacky information and slight samples; and

- due to poor incomplete information and uncertainty, the grey systems theory plays a major role in several decision-making problems.

\section{Developed model: a novel Grey integrated approach of AHP and WASPAS}

The multi-criteria decision-making (MCDM) techniques are generally employed to measure the alternatives for future decisions. It is considered as one of the most useful methods in operations research that entails a broader set of techniques that are appropriate to overcome the complexity of supplier evaluation and selection. In this paper, a novel Grey integrated model of AHP and WASPAS is developed to determine the best supplier for a Turkish textile company.

\subsection{The Grey Analytic Hierarchy (G-AHP) model for weighting the criteria of suppliers}

The G-AHP, which is employed to define the weights of criteria, consists of three main strides that could be displayed as follows (Ulutaş, 2016);

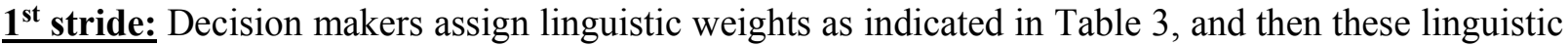
weights are transformed into grey weights by utilising Table 3 . After this process, the grey comparison matrix $(\otimes Z)$ is structured as follows:

$\otimes \mathrm{Z}=\left(\otimes z_{i j}\right)_{n \times n}$

where

$$
\otimes z_{i j}=\left[\underline{z_{i j}}, \overline{z_{i j}}\right] \text { and } z_{i j}^{-1}=\left[\frac{1}{\overline{z_{i j}}}, \frac{1}{z_{i j}}\right]
$$


In Eq. (2), $z_{i j}$ and $\overline{z_{i j}}$ indicate the minimum and the maximum values of $\otimes z_{i j}$ correspondingly.

\section{Table 3}

Linguistic terms and their Grey Weights

\begin{tabular}{ll}
\hline Linguistic Weights & Grey Weights \\
\hline Absolute Significant (AS) & {$[7,9]$} \\
More Significant (MS) & {$[5,7]$} \\
Significant (S) & {$[3,5]$} \\
Moderately Significant (MS) & {$[1,3]$} \\
Equal Significant (ES) & {$[1,1]$} \\
\hline
\end{tabular}

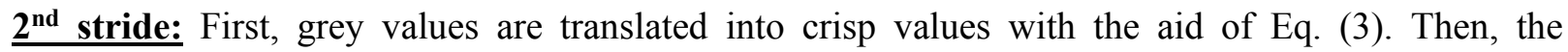
consistency of the grey matrix is analysed with Eq. (4) and Eq. (5) (Saaty, 1990). If $C R$ is $<0.1$ the study directly moves to step 3 .

$$
\begin{aligned}
& z_{i j}=\frac{1}{2} \times\left(\underline{z_{i j}}+\overline{z_{i j}}\right) \\
& C I=\frac{\left(\nabla_{\text {max }}-n\right)}{(n-1)} \\
& C R=\left(\frac{C I}{R I}\right)
\end{aligned}
$$

$\underline{3}^{\text {rd }}$ stride: By applying Eq. (6) (the row sums of $\otimes Z$ ) and by also using Eq. (8) and Eq. (9), the grey row sums $\left(\otimes Y_{i}\right)$ are normalized to define the grey weight $\left(\otimes w_{i}\right)$ of each criterion. These values are afterwards transferred into WASPAS-G.

$$
\begin{aligned}
& \otimes Y_{i}=\sum_{j=1}^{n}\left[\underline{z_{i j}}, \overline{z_{i j}}\right] \\
& \otimes Y_{i}=\left[\underline{Y_{i}}, \overline{Y_{i}}\right] \\
& \underline{Y_{i}^{*}}=\left[\frac{2 \times \underline{Y_{i}}}{\sum_{i=1}^{n} \underline{Y_{i}}+\sum_{i=1}^{n} \overline{Y_{i}}}\right] \\
& \overline{2} \times \overline{Y_{i}} \\
& \overline{Y_{i}^{*}}=\left[\frac{1}{\sum_{i=1}^{n} \underline{Y}_{i}+\sum_{i=1}^{n} \overline{Y_{i}}}\right] \\
& \otimes w_{i}=\left[\underline{Y_{i}^{*}}, \overline{Y_{i}^{*}}\right]=\left[\underline{w_{i}}, \overline{w_{i}}\right]
\end{aligned}
$$

\subsection{The Grey weighted aggregated sum product assessment(WASPAS-G) model for prioritising the criteria of suppliers}

According to Zavadskas et al. (2015), the WASPAS-G model normally entails four main steps. The present study adopts the process of four steps as well to prioritise the appropriate criteria in supplier selection and evaluation procedure. These essential strides are presented as follows;

$\underline{\mathbf{1}^{\text {st }} \text { stride: }}$ A grey decision matrix is structured with regard to the preferences of decision makers. First, they assign linguistic values as shown in Table 4 . Then, these defined values are converted into grey values in order to construct the grey decision matrix $(\otimes T)$.

$$
\otimes T=\left[\begin{array}{ccccc}
\otimes t_{11} & \cdots & \otimes t_{1 i} & \ldots & \otimes t_{1 n} \\
\vdots & \ddots & \vdots & \ddots & \vdots \\
\otimes t_{v 1} & \cdots & \otimes t_{v i} & \cdots & \otimes t_{v n} \\
\vdots & \ddots & \vdots & \ddots & \vdots \\
\otimes t_{m 1} & \cdots & \otimes t_{m i} & \cdots & \otimes t_{m n}
\end{array}\right]
$$


Table 4

Linguistic terms and an their Grey Values

\begin{tabular}{lc}
\hline Linguistic Values & Grey Values \\
\hline Very Poor (VP) & {$[0,0.20]$} \\
Poor (P) & {$[0.10,0.30]$} \\
Medium Poor (MP) & {$[0.20,0.40]$} \\
Fair (F) & {$[0.35,0.65]$} \\
Medium Good (MG) & {$[0.60,0.80]$} \\
Good (G) & {$[0.70,0.90]$} \\
Very Good (VG) & {$[0.80,1]$} \\
\hline
\end{tabular}

Source: Adapted from Zavadskas et al. (2015)

$2^{\text {nd }}$ stride: Each value in the grey decision matrix $(\otimes T)$ is normalized by using Eq. (12) (beneficial criteria) and Eq. (13) (non-beneficial criteria). In Eqs. (12-13), $\otimes t_{v i}^{\prime}$ denotes the grey normalized value.

$$
\otimes t_{v i}^{\prime}=\frac{\otimes t_{v i}}{\max _{v} \otimes t_{v i}}=\left[\frac{t_{v i}}{\max _{v} \overline{t_{v i}}}, \frac{\overline{t_{v i}}}{\max _{v} \overline{t_{v i}}}\right]
$$

where

$$
\otimes t_{v i}^{\prime}=\frac{\min _{v} \otimes t_{v i}}{\otimes t_{v i}}=\left[\frac{\min _{v} t_{v i}}{\overline{t_{v i}}}, \frac{\min _{v} \underline{t_{v i}}}{\underline{t_{v i}}}\right]
$$

$\underline{3^{\text {rd }} \text { stride: }}$ The grey weighted sum model $\left(\otimes B_{v}=\left(\underline{B_{v}}, \overline{B_{v}}\right)\right)$ and the grey weighted product model $\left(\otimes K_{v}=\left(K_{v}, \overline{K_{v}}\right)\right)$ are obtained by using Eq. (14) and Eq. (15) respectively. Then, these grey values are transformed into crisp values $\left(B_{v}, K_{v}\right)$ by setting Eq. (16) and Eq. (17), respectively.

$$
\begin{aligned}
& \otimes B_{v}=\sum_{i=1}^{n} \otimes t_{v i}^{\prime} \times \otimes w_{i}=\left[\sum_{i=1}^{n} \underline{t_{v i}^{\prime}} \times \underline{w_{i}}, \sum_{i=1}^{n} \overline{t_{v i}^{\prime}} \times \overline{w_{i}}\right] \\
& \otimes K_{v}=\prod_{i=1}^{n}\left(\otimes t^{\prime}\right)^{\otimes w_{i}}=\left[\prod_{i=1}^{n}\left(\underline{t_{v i}^{\prime}}\right)^{\frac{w_{i}}{n}}, \prod_{i=1}^{n}\left(\overline{t_{v i}^{\prime}}\right)^{\overline{w_{i}}}\right] \\
& B_{v}=\frac{B_{v}+\overline{B_{v}}}{2} \\
& K_{v}=\frac{\frac{K_{v}}{2}+\overline{K_{v}}}{2}
\end{aligned}
$$

$4^{\text {th }}$ stride: The final score for each supplier can be achieved by using Eq. (18). The $A_{v}$ herein denotes the ultimate value of $v$ th supplier. Furthermore, the supplier that encompasses the highest final score is selected as the most appropriate supplier in the supply chain.

$$
A_{v}=\gamma B_{v}+(1-\gamma) K_{v}
$$

where

$$
\gamma=0.5 \frac{\sum_{v=1}^{m} K_{v}}{\sum_{v=1}^{m} B_{v}}
$$

\section{Real world case study}

In the present paper, the development of the grey integrated model is applied and verified within a Turkish textile company that normally belongs to the garment sector in Turkey. A very qualified team, involving the factory manager, deputy director, and the industrial engineer, was consulted. As mentioned above, the present study focuses on eight main criteria with regard to the textile company supplier selection strategy requirements. However, this range of criteria is presented as follows: 
- Quality (Q),

- Cost (C),

- Technological Capability (TC),

- Technical Support (TS),

- Delivery (D),

- Flexibility (F),

- $\quad$ Supplier Reputation (SR), and

- Discount Opportunities (DO).

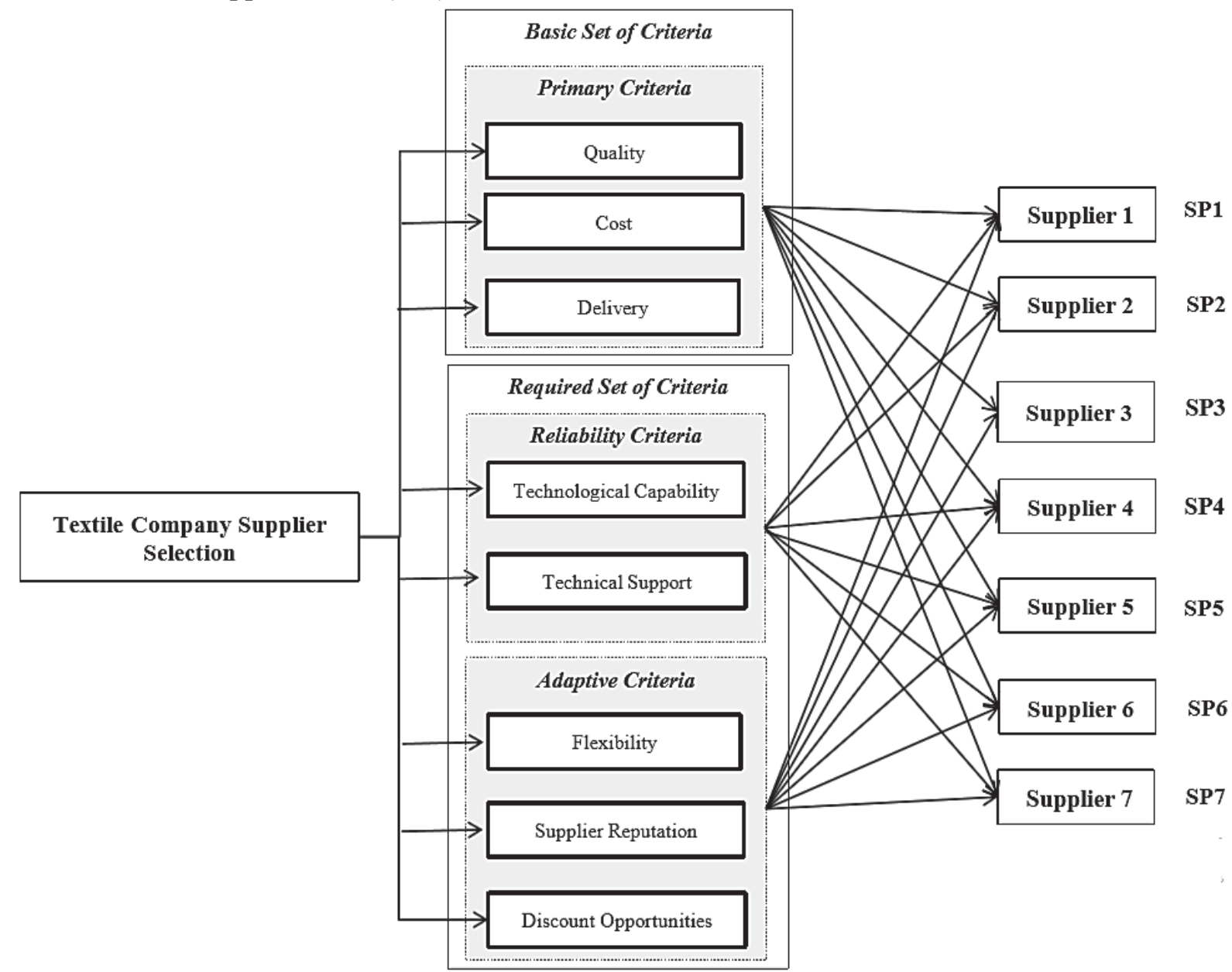

Fig. 1. Set of criteria for selecting the right supplier in Turkish Textile Company

The grey comparison matrix is constructed with the support and the assessments of this qualified team. The grey comparison matrix is illustrated in detail in Table 5.

Table 5

Grey Constructed Comparison Matrix

\begin{tabular}{lcccc}
\hline & & & Criteria & \\
Criteria & $\mathrm{Q}$ & $\mathrm{C}$ & $\mathrm{TC}$ & $\mathrm{TS}$ \\
\hline $\mathrm{Q}$ & {$[1,1]$} & {$[1,3]$} & {$[3,5]$} & {$[3,5]$} \\
C & {$[0.333,1]$} & {$[1,1]$} & {$[3,5]$} & {$[3,5]$} \\
TC & {$[0.2,0.333]$} & {$[0.2,0.333]$} & {$[1,1]$} & {$[3,5]$} \\
TS & {$[0.2,0.333]$} & {$[0.2,0.333]$} & {$[0.2,0.333]$} & {$[1,1]$} \\
D & {$[1,1]$} & {$[1,1]$} & {$[3,5]$} & {$[3,5]$} \\
F & {$[0.2,0.333]$} & {$[0.2,0.333]$} & {$[1,1]$} & {$[0.333,1]$} \\
SR & {$[0.2,0.333]$} & {$[0.2,0.333]$} & {$[0.2,0.333]$} & {$[0.333,1]$} \\
DO & {$[0.2,0.333]$} & {$[0.2,0.333]$} & {$[0.2,0.333]$} & {$[1,1]$} \\
\hline
\end{tabular}




\begin{tabular}{lcccc}
\hline & & & Criteria & \\
Criteria & $\mathrm{D}$ & $\mathrm{F}$ & $\mathrm{SR}$ & $\mathrm{DO}$ \\
\hline $\mathrm{Q}$ & {$[1,1]$} & {$[3,5]$} & {$[3,5]$} & {$[3,5]$} \\
$\mathrm{C}$ & {$[1,1]$} & {$[3,5]$} & {$[3,5]$} & {$[3,5]$} \\
TC & {$[0.2,0.333]$} & {$[1,1]$} & {$[3,5]$} & {$[3,5]$} \\
TS & {$[0.2,0.333]$} & {$[1,3]$} & {$[1,3]$} & {$[1,1]$} \\
$\mathrm{D}$ & {$[1,1]$} & {$[3,5]$} & {$[5,7]$} & {$[3,5]$} \\
F & {$[0.2,0.333]$} & {$[1,1]$} & {$[3,5]$} & {$[1,1]$} \\
SR & {$[0.143,0.2]$} & {$[0.2,0.333]$} & {$[1,1]$} & {$[0.2,0.333]$} \\
DO & {$[0.2,0.333]$} & {$[1,1]$} & {$[3,5]$} & {$[1,1]$} \\
\hline
\end{tabular}

The row sums of the grey comparison matrix and the grey weights of criteria are shown in Table 6 .

Table 6

The Results of G-AHP model

\begin{tabular}{|c|c|c|}
\hline \multirow[b]{2}{*}{ Criteria } & \multicolumn{2}{|c|}{ Results } \\
\hline & $\otimes Y_{i}$ & $\otimes w_{i}$ \\
\hline $\mathrm{Q}$ & {$[18,30]$} & {$[0.159,0.265]$} \\
\hline $\mathrm{C}$ & {$[17.333,28]$} & {$[0.153,0.247]$} \\
\hline $\mathrm{TC}$ & {$[11.6,17.999]$} & {$[0.102,0.159]$} \\
\hline TS & {$[4.8,9.332]$} & {$[0.042,0.082]$} \\
\hline $\mathrm{D}$ & {$[20,30]$} & {$[0.177,0.265]$} \\
\hline $\mathrm{F}$ & {$[6.933,9.999]$} & {$[0.061,0.088]$} \\
\hline SR & {$[2.476,3.865]$} & {$[0.022,0.034]$} \\
\hline DO & {$[6.8,9.332]$} & {$[0.060,0.082]$} \\
\hline
\end{tabular}

After using G-AHP, the grey decision matrix, which is structured with regard to the preferences of decision makers, is explained in Table 7. The value of the consistency rate of G-AHP model is less than 0.1 which means that the collected data from the decision makers is feasible and reliable.

Table 7

Grey Constructed Decision Matrix

\begin{tabular}{lcccc}
\hline & \multicolumn{3}{c}{ Criteria } \\
\cline { 2 - 5 } Supplier & $\mathrm{Q}$ & $\mathrm{C}$ & $\mathrm{TC}$ & $\mathrm{TS}$ \\
\hline SP1 & {$[0.60,0.80]$} & {$[0.70,0.90]$} & {$[0.35,0.65]$} & {$[0.20,0.40]$} \\
SP1 & {$[0.70,0.90]$} & {$[0.60,0.80]$} & {$[0.60,0.80]$} & {$[0.20,0.40]$} \\
SP3 & {$[0.70,0.90]$} & {$[0.60,0.80]$} & {$[0.35,0.65]$} & {$[0.35,0.65]$} \\
SP4 & {$[0.60,0.80]$} & {$[0.70,0.90]$} & {$[0.20,0.40]$} & {$[0.20,0.40]$} \\
SP5 & {$[0.60,0.80]$} & {$[0.60,0.80]$} & {$[0.60,0.80]$} & {$[0.35,0.65]$} \\
SP6 & {$[0.70,0.90]$} & {$[0.60,0.80]$} & {$[0.35,0.65]$} & {$[0.20,0.40]$} \\
SP7 & {$[0.60,0.80]$} & {$[0.60,0.80]$} & {$[0.20,0.40]$} & {$[0.35,0.65]$} \\
\hline & & & & \\
Supplier & $\mathrm{D}$ & $\mathrm{F}$ & $\mathrm{SR}$ & $\mathrm{DO}$ \\
\hline SP1 & {$[0.35,0.65]$} & {$[0.35,0.65]$} & {$[0.35,0.65]$} & {$[0.35,0.65]$} \\
SP2 & {$[0.35,0.65]$} & {$[0.35,0.65]$} & {$[0.60,0.80]$} & {$[0.10,0.30]$} \\
SP3 & {$[0.35,0.65]$} & {$[0.60,0.80]$} & {$[0.60,0.80]$} & {$[0.10,0.30]$} \\
SP4 & {$[0.20,0.40]$} & {$[0.60,0.80]$} & {$[0.35,0.65]$} & {$[0.35,0.65]$} \\
SP5 & {$[0.20,0.40]$} & {$[0.35,0.65]$} & {$[0.35,0.65]$} & {$[0.35,0.65]$} \\
SP6 & {$[0.35,0.65]$} & {$[0.35,0.65]$} & {$[0.35,0.65]$} & {$[0.35,0.65]$} \\
SP7 & {$[0.35,0.65]$} & {$[0.60,0.80]$} & {$[0.35,0.65]$} & {$[0.35,0.65]$} \\
\hline
\end{tabular}

Eq. (12) and Eq. (13) are integrated into the grey decision matrix in order to convert grey values, in the same matrix, into grey normalized values. These normalized values are given in Table 8 . 


\section{Table 8}

Grey Normalized Values

\begin{tabular}{|c|c|c|c|c|}
\hline \multirow[b]{2}{*}{ Supplier } & \multicolumn{4}{|c|}{ Criteria } \\
\hline & $Q$ & $\mathrm{C}$ & $\mathrm{TC}$ & $\mathrm{TS}$ \\
\hline SP1 & {$[0.667,0.889]$} & {$[0.667,0.857]$} & {$[0.438,0.813]$} & {$[0.308,0.615]$} \\
\hline SP2 & {$[0.778,1]$} & {$[0.750,1]$} & {$[0.750,1]$} & {$[0.308,0.615]$} \\
\hline SP3 & {$[0.778,1]$} & {$[0.750,1]$} & {$[0.438,0.813]$} & {$[0.538,1]$} \\
\hline SP4 & {$[0.667,0.889]$} & {$[0.667,0.857]$} & {$[0.250,0.500]$} & {$[0.308,0.615]$} \\
\hline SP5 & {$[0.667,0.889]$} & {$[0.750,1]$} & {$[0.750,1]$} & {$[0.538,1]$} \\
\hline SP6 & {$[0.778,1]$} & {$[0.750,1]$} & {$[0.438,0.813]$} & {$[0.308,0.615]$} \\
\hline \multirow[t]{2}{*}{ SP7 } & {$[0.667,0.889]$} & {$[0.750,1]$} & {$[0.250,0.500]$} & {$[0.538,1]$} \\
\hline & \multicolumn{4}{|c|}{ Criteria } \\
\hline Supplier & $\mathrm{D}$ & $\mathrm{F}$ & SR & DO \\
\hline SP1 & {$[0.538,1]$} & {$[0.438,0.813]$} & {$[0.438,0.813]$} & {$[0.538,1]$} \\
\hline SP2 & {$[0.538,1]$} & {$[0.438,0.813]$} & {$[0.750,1]$} & {$[0.154,0.462]$} \\
\hline SP3 & {$[0.538,1]$} & {$[0.750,1]$} & {$[0.750,1]$} & {$[0.154,0.462]$} \\
\hline SP4 & {$[0.308,0.615]$} & {$[0.750,1]$} & {$[0.438,0.813]$} & {$[0.538,1]$} \\
\hline SP5 & {$[0.308,0.615]$} & {$[0.438,0.813]$} & {$[0.438,0.813]$} & {$[0.538,1]$} \\
\hline SP6 & {$[0.538,1]$} & {$[0.438,0.813]$} & {$[0.438,0.813]$} & {$[0.538,1]$} \\
\hline SP7 & {$[0.538,1]$} & {$[0.750,1]$} & {$[0.438,0.813]$} & {$[0.538,1]$} \\
\hline
\end{tabular}

Eq. (14) is employed in this present work to compute the grey weighted sum model $\left(\otimes B_{v}\right)$. This obtained grey value is consistently converted into crisp value $\left(B_{v}\right)$ with the help of Eq. (16). Additionally, Eq. (15) is obviously used in this case to calculate the grey weighted product model $(\otimes$ $\left.K_{v}\right)$. This attained grey value is also converted into crisp value $\left(K_{v}\right)$ with the help of Eq. (17). Furthermore, the use of Eq. (18) leads the study to the final destination where the final score of each supplier revealed. Table 9 explains in details the outcomes of the constructed WASPAS-G model.

\section{Table 9}

Final results of the constructed Grey model

\begin{tabular}{lccc}
\hline & & Results & $B_{v}$ \\
\hline Suppliers & $\otimes B_{v}$ & $\otimes K_{v}$ & 0.752 \\
\hline SP1 & {$[0.430,1.074]$} & {$[0.621,0.846]$} & 0.804 \\
SP2 & {$[0.476,1.131]$} & {$[0.643,0.885]$} & 0.811 \\
SP3 & {$[0.473,1.149]$} & {$[0.644,0.908]$} & 0.664 \\
SP4 & {$[0.389,0.939]$} & {$[0.549,0.701]$} & 0.757 \\
SP5 & {$[0.444,1.069]$} & {$[0.620,0.831]$} & 0.800 \\
SP6 & {$[0.460,1.139]$} & {$[0.648,0.906]$} & 0.780 \\
SP7 & {$[0.452,1.108]$} & {$[0.632,0.862]$} & Ranks \\
\hline & & Results & $\mathbf{5}$ \\
Supplier & $K_{v}$ & $A_{v}$ & $\mathbf{3}$ \\
\hline SP1 & 0.734 & 0.743 & $\mathbf{1}$ \\
SP2 & 0.764 & 0.785 & $\mathbf{7}$ \\
SP3 & $\mathbf{0 . 7 7 6}$ & 0.794 & $\mathbf{6}$ \\
SP4 & 0.625 & 0.745 & $\mathbf{2}$ \\
SP5 & 0.726 & 0.789 & $\mathbf{4}$ \\
SP6 & 0.777 & 0.764 & \\
SP7 & 0.747 & & \\
\hline
\end{tabular}

Supplier 3 (SP 3) is presented to be the most appropriate alternative among the seven alternatives. According to the final results generated in Table 9, the relative closeness of the supplier 3 is high with values of 0.776 and 0.794 . While the second appropriate alternative is the supplier 6 with values of and 0.777 and 0.789 . 


\section{Results and discussions}

From the model reliability perspective, the Grey AHP and Grey WASPAS model results reveal that supplier 3 is the appropriate supplier amidst other seven suppliers followed by the Turkish Textile Company. However, the model results also show that the supplier with the worst performance highlighted as supplier 4 as demonstrated in Table 9. The use of Grey AHP model in the present work provides constant criteria weighting while Grey WASPAS model generates suppliers (alternatives) rankings with regard to the company requirements. The Grey integrated model is able to offer precise information in very less complexity. In other words, the supplier selection and evaluation procedure are achieved in a limited number of steps and operations. From the academic perspective, the present study presents a Grey integrated model consisting of AHP-WASPAS for supplier selection and evaluation under an uncertain and non-quantitative environment. The main challenge addressed within this work is to assess all the risks and complexities found during the process of selecting the right supplier due to the ambiguity of the collected data in very less time. However, the final results affirm that this approach could be applied within other sectors and with the employment of a broader range of criteria and sub-criteria. Furthermore, the novel constructed grey integrated multi-criteria approach could be effective and useful for other future researches in the variable fields of study, due to its simplicity and applicability in a very short time, such as industry, military, medicine, biology, agriculture, ecology and so on.

\section{Conclusion}

This study has proposed a novel approach appropriate for Textile Company for selection of the most appropriate supplier in the supply chain in Turkey. The seven important suppliers and the eight essential criteria were examined in the context of overcoming the obstacle in selecting the resilient supplier to Textile Company. In addition, this paper has underlined the two main contributions: (1) Accordingly, it has revealed that there was a limited number of studies that combined the Grey systems theory approach with MCDM techniques, specifically G-AHP and WASPAS-G, to solve the problem of supplier selection and overcome the complexity of the procedure during the application in the supply chain. (2) Subsequently, this paper has developed a novel grey integrated multi-criteria approach that could be regarded as a convenient framework for any other future research with the application of an unlimited number of criteria especially when the decision-maker has limited access to data and is usually exposed to the fuzzy environment in the context of human judgments.

\section{Acknowledgement}

The authors would like to thank Centre National pour la Recherche Scientifique et Technique CNRST for supporting the accomplishment of this paper.

\section{References}

Ali, Y., Khan, J., Awan, M. A., \& Bilal, M. (2018). Supplier Selection for Oil Refinery by using MCDM Approach: case of Pakistan Refinery Limited (PRL) in a point.

Amid, A., Ghodsypour, S. H., \& O'Brien, C. (2009). A weighted additive fuzzy multiobjective model for the supplier selection problem under price breaks in a supply chain. International Journal of Production Economics, 121(2), 323-332.

Arikan, F. (2013). A fuzzy solution approach for multi objective supplier selection. Expert Systems with Applications, 40(3), 947-952.

Awasthi, A., \& Kannan, G. (2016). Green supplier development program selection using NGT and VIKOR under fuzzy environment. Computers \& Industrial Engineering, 91, 100-108.

Bai, C., \& Sarkis, J. (2010). Integrating sustainability into supplier selection with grey system and rough set methodologies. International Journal of Production Economics, 124(1), 252-264.

Bai, C., \& Sarkis, J. (2014). Determining and applying sustainable supplier key performance indicators. Supply Chain Management: An International Journal, 19(3), 275-291. 
Bai, C., Kusi-Sarpong, S., Badri Ahmadi, H., \& Sarkis, J. (2019). Social sustainable supplier evaluation and selection: a group decision-support approach. International Journal of Production Research, 1-22.

Bakeshlou, E. A., Khamseh, A. A., Asl, M. A. G., Sadeghi, J., \& Abbaszadeh, M. (2017). Evaluating a green supplier selection problem using a hybrid MODM algorithm. Journal of Intelligent Manufacturing, 28(4), 913-927.

Beşkese, A., \& Şakra, A. (2010). A model proposal for supplier selection in automotive industry. In 14th international research/expert conference TMT.

Boran, F. E., Genç, S., Kurt, M., \& Akay, D. (2009). A multi-criteria intuitionistic fuzzy group decision making for supplier selection with TOPSIS method. Expert Systems with Applications, 36(8), 11363-11368.

Büyüközkan, G., \& Çifçi, G. (2011). A novel fuzzy multi-criteria decision framework for sustainable supplier selection with incomplete information. Computers in industry, 62(2), 164-174.

Büyüközkan, G., \& Çifçi, G. (2012). A novel hybrid MCDM approach based on fuzzy DEMATEL, fuzzy ANP and fuzzy TOPSIS to evaluate green suppliers. Expert Systems with Applications, 39(3), 3000-3011.

Büyüközkan, G., \& Göçer, F. (2017). Application of a new combined intuitionistic fuzzy MCDM approach based on axiomatic design methodology for the supplier selection problem. Applied Soft Computing, 52, 1222-1238.

Chakraborty, S., Zavadskas, E. K., \& Antucheviciene, J. (2015). Applications of WASPAS method as a multicriteria decision-making tool. Economic Computation \& Economic Cybernetics Studies \& Research, 49(1).

Chang, B., Chang, C. W., \& Wu, C. H. (2011). Fuzzy DEMATEL method for developing supplier selection criteria. Expert systems with Applications, 38(3), 1850-1858.

Chen, I. J., Paulraj, A., \& Lado, A. A. (2004). Strategic purchasing, supply management, and firm performance. Journal of Operations Management, 22(5), 505-523.

Cheng, B. (1986). The grey control on industrial process. Journal of Huangshi College, 1(1), 11-23.

Christopher, M., \& Peck, H. (2004). Building the resilient supply chain. The International Journal of Logistics Management, 15(2), 1-14.

De Boer, L., van der Wegen, L., \& Telgen, J. (1998). Outranking methods in support of supplier selection. European Journal of Purchasing \& Supply Management, 4(2-3), 109-118.

Deng, X., Hu, Y., Deng, Y., \& Mahadevan, S. (2014). Supplier selection using AHP methodology extended by D numbers. Expert Systems with Applications, 41(1), 156-167.

Deng, Y., \& Chan, F. T. (2011). A new fuzzy dempster MCDM method and its application in supplier selection. Expert Systems with Applications, 38(8), 9854-9861.

Deshmukh, S., \& Sunnapwar, V. (2019). Fuzzy Analytic Hierarchy Process (FAHP) for Green Supplier Selection in Indian Industries. In Proceedings of International Conference on Intelligent Manufacturing and Automation (pp. 679-687). Springer, Singapore.

Dou, Y., Zhu, Q., \& Sarkis, J. (2014). Evaluating green supplier development programs with a grey-analytical network process-based methodology. European Journal of Operational Research, 233(2), 420-431.

Dursun, M., \& Karsak, E. E. (2013). A QFD-based fuzzy MCDM approach for supplier selection. Applied Mathematical Modelling, 37(8), 5864-5875.

Ghorbani, M., Mohammad Arabzad, S., \& Shahin, A. (2013). A novel approach for supplier selection based on the Kano model and fuzzy MCDM. International Journal of Production Research, 51(18), 5469-5484.

Goh, M., Shuya, Z., \& de Souza, R. (2018). Operational Framework for Healthcare Supplier Selection Under a Fuzzy Multi-Criteria Environment. In 23rd International Symposium on Logistics (ISL 2018) Big Data Enabled Supply Chain Innovations.

Güneri, A. F., Ertay, T., \& Yücel, A. (2011). An approach based on ANFIS input selection and modeling for supplier selection problem. Expert Systems with Applications, 38(12), 14907-14917.

Gürler, A. G. İ. (2007). Supplier selection criteria of Turkish automotive industry. Journal of Yaşar University, 2(6), 555-569.

Haeri, S. A. S., \& Rezaei, J. (2019). A grey-based green supplier selection model for uncertain environments. Journal of Cleaner Production.

Haldar, A., Ray, A., Banerjee, D., \& Ghosh, S. (2012). A hybrid MCDM model for resilient supplier selection. International Journal of Management Science and Engineering Management, 7(4), 284-292.

Hamdan, S., \& Cheaitou, A. (2017). Supplier selection and order allocation with green criteria: An MCDM and multi-objective optimization approach. Computers \& Operations Research, 81, 282-304.

Handfield, R., Walton, S. V., Sroufe, R., \& Melnyk, S. A. (2002). Applying environmental criteria to supplier assessment: a study in the application of the analytical hierarchy process. European journal of operational research, 141(1), 70-87. 
Ho, W., Xu, X., \& Dey, P. K. (2010). Multi-criteria decision making approaches for supplier evaluation and selection: A literature review. European Journal of Operational Research, 202(1), 16-24.

Jato-Espino, D., Castillo-Lopez, E., Rodriguez-Hernandez, J., \& Canteras-Jordana, J. C. (2014). A review of application of multi-criteria decision making methods in construction. Automation in Construction, 45, 151162.

Jiang, P., Hu, Y. C., Yen, G. F., \& Tsao, S. J. (2018). Green supplier selection for sustainable development of the automotive industry using grey decision-making. Sustainable Development, 26(6), 890-903.

Julong, D. (1984). The theory and methods of socio-economic grey systems. Social Science in China, 6.

Julong, D. (1986). Grey prediction and decision. Publishing House of Huazhong University of Technology.

Kahraman, C., \& Kaya, İ. (2010). Supplier selection in agile manufacturing using fuzzy analytic hierarchy process. In Enterprise networks and logistics for agile manufacturing (pp. 155-190). Springer, London.

Kar, A. K. (2014). Revisiting the supplier selection problem: An integrated approach for group decision support. Expert systems with applications, 41(6), 2762-2771.

Karsak, E. E., \& Dursun, M. (2015). An integrated fuzzy MCDM approach for supplier evaluation and selection. Computers \& Industrial Engineering, 82, 82-93.

Khodadadzadeh, T., \& Sadjadi, S. (2013). A state-of-art review on supplier selection problem. Decision Science Letters, 2(2), 59-70.

Kumar Kar, A., \& K. Pani, A. (2014). Exploring the importance of different supplier selection criteria. Management Research Review, 37(1), 89-105.

Lambert, D. M., \& Cooper, M. C. (2000). Issues in supply chain management. Industrial Marketing Management, 29(1), 65-83.

Lee, E. K., Ha, S., \& Kim, S. K. (2001). Supplier selection and management system considering relationships in supply chain management. IEEE transactions on Engineering Management, 48(3), 307-318.

Li, G. D., Yamaguchi, D., \& Nagai, M. (2007). A grey-based decision-making approach to the supplier selection problem. Mathematical and Computer Modelling, 46(3-4), 573-581.

Li, J., \& Wang, J. Q. (2017). An extended QUALIFLEX method under probability hesitant fuzzy environment for selecting green suppliers. International Journal of Fuzzy Systems, 19(6), 1866-1879.

Li, S., Ragu-Nathan, B., Ragu-Nathan, T. S., \& Rao, S. S. (2006). The impact of supply chain management practices on competitive advantage and organizational performance. Omega, 34(2), 107-124.

Lin, C. T., Chen, C. B., \& Ting, Y. C. (2011). An ERP model for supplier selection in electronics industry. Expert Systems with Applications, 38(3), 1760-1765.

Liu, H. C., Quan, M. Y., Li, Z., \& Wang, Z. L. (2019). A new integrated MCDM model for sustainable supplier selection under interval-valued intuitionistic uncertain linguistic environment. Information Sciences.

Liu, T., Deng, Y., \& Chan, F. (2018). Evidential supplier selection based on DEMATEL and game theory. International Journal of Fuzzy Systems, 20(4), 1321-1333.

Luo, X., Wu, C., Rosenberg, D., \& Barnes, D. (2009). Supplier selection in agile supply chains: An informationprocessing model and an illustration. Journal of Purchasing and Supply Management, 15(4), 249-262.

Memon, M. S., Lee, Y. H., \& Mari, S. I. (2015). Group multi-criteria supplier selection using combined grey systems theory and uncertainty theory. Expert Systems with Applications, 42(21), 7951-7959.

Mohammed, A., Harris, I., \& Kannan, G. (2019). A hybrid MCDM-FMOO approach for sustainable supplier selection and order allocation. International Journal of Production Economics.

Monczka, R. M., Petersen, K. J., Handfield, R. B., \& Ragatz, G. L. (1998). Success factors in strategic supplier alliances: the buying company perspective. Decision Sciences, 29(3), 553-577.

Nallusamy, S., Kumar, D., Balakannan, K., \& Chakraborty, P. S. (2016). MCDM tools application for selection of suppliers in manufacturing industries using AHP, FUZZY LOGIC AND ANN. International Journal of Engineering Research in Africa, 19.

Önüt, S., Kara, S. S., \& Işik, E. (2009). Long term supplier selection using a combined fuzzy MCDM approach: A case study for a telecommunication company. Expert Systems with Applications, 36(2), 3887-3895.

Parkouhi, S. V., \& Ghadikolaei, A. S. (2017). A resilience approach for supplier selection: Using fuzzy analytic network process and grey VIKOR techniques. Journal of Cleaner Production, 161, 431-451.

Quan, M. Y., Wang, Z. L., Liu, H. C., \& Shi, H. (2018). A hybrid MCDM approach for large group green supplier selection with uncertain linguistic information. IEEE Access, 6, 50372-50383.

Rezaei, J., \& Ortt, R. (2013). Supplier segmentation using fuzzy logic. Industrial Marketing Management, 42(4), 507-517.

Rezaei, J., Nispeling, T., Sarkis, J., \& Tavasszy, L. (2016). A supplier selection life cycle approach integrating traditional and environmental criteria using the best worst method. Journal of Cleaner Production, 135, 577588 . 
Rezaeisaray, M., Ebrahimnejad, S., \& Khalili-Damghani, K. (2016). A novel hybrid MCDM approach for outsourcing supplier selection: A case study in pipe and fittings manufacturing. Journal of Modelling in Management, 11(2), 536-559.

Saaty, T. L. (1990). How to make a decision: the analytic hierarchy process. European journal of operational research, 48(1), 9-26.

Saeedpoor, M. (2012). Ranking the elements of SWOT matrix with the approach of combining Gray theory and.

Sagar, M. K., \& Singh, D. (2012). Supplier selection criteria: study of automobile sector in India. International Journal of Engineering Research and Development, 4(4), 34-39.

Sanayei, A., Mousavi, S. F., \& Yazdankhah, A. (2010). Group decision making process for supplier selection with VIKOR under fuzzy environment. Expert Systems with Applications, 37(1), 24-30.

Sarkis, J., \& Talluri, S. (2002). A model for strategic supplier selection. Journal of Supply Chain Management, $38(4), 18-28$.

Şen, C. G., Baraçlı, H., Şen, S., \& Başlıgil, H. (2009). An integrated decision support system dealing with qualitative and quantitative objectives for enterprise software selection. Expert Systems with Applications, $36(3), 5272-5283$.

Shemshadi, A., Shirazi, H., Toreihi, M., \& Tarokh, M. J. (2011). A fuzzy VIKOR method for supplier selection based on entropy measure for objective weighting. Expert Systems with Applications, 38(10), 12160-12167.

Steven, A. B., Dong, Y., \& Corsi, T. (2014). Global sourcing and quality recalls: An empirical study of outsourcing-supplier concentration-product recalls linkages. Journal of Operations Management, 32(5), 241253.

Tseng, M. L. (2009). A causal and effect decision making model of service quality expectation using grey-fuzzy DEMATEL approach. Expert Systems with Applications, 36(4), 7738-7748.

Ulutaş (2016), A Grey Group Decision-Making Model to Solve Supplier Selection Problem for a Textile Company, 16. Üretim Araştırmaları Sempozyumu, İstanbul.

Ulutas, A., Shukla, N., Kiridena, S., \& Gibson, P. (2016). A utility-driven approach to supplier evaluation and selection: empirical validation of an integrated solution framework. International Journal of Production Research, 54(5), 1554-1567.

Wan, S. P., Xu, G. L., \& Dong, J. Y. (2017). Supplier selection using ANP and ELECTRE II in interval 2-tuple linguistic environment. Information Sciences, 385, 19-38.

Wang Chen, H. M., Chou, S. Y., Luu, Q. D., \& Yu, T. H. K. (2016). A fuzzy MCDM approach for green supplier selection from the economic and environmental aspects. Mathematical Problems in Engineering, 2016.

Wang, J. W., Cheng, C. H., \& Huang, K. C. (2009). Fuzzy hierarchical TOPSIS for supplier selection. Applied Soft Computing, 9(1), 377-386.

Ware, N., Sing, S., \& Banwet, D. (2012). Supplier selection problem: A state-of-the-art review. Management Science Letters, 2(5), 1465-1490.

Weber, C. A. (1991). A decision support system using multi-criteria techniques for vendor selection (Doctoral dissertation, The Ohio State University).

Wu, D. D., Zhang, Y., Wu, D., \& Olson, D. L. (2010). Fuzzy multi-objective programming for supplier selection and risk modeling: A possibility approach. European Journal of Operational Research, 200(3), 774-787.

Xia, X., Govindan, K., \& Zhu, Q. (2015). Analyzing internal barriers for automotive parts remanufacturers in China using grey-DEMATEL approach. Journal of Cleaner Production, 87, 811-825.

Yazdani, M., Chatterjee, P., Zavadskas, E. K., \& Zolfani, S. H. (2017). Integrated QFD-MCDM framework for green supplier selection. Journal of Cleaner Production, 142, 3728-3740.

Yazdani, M., Hashemkhani Zolfani, S., \& Zavadskas, E. K. (2016). New integration of MCDM methods and QFD in the selection of green suppliers. Journal of Business Economics and Management, 17(6), 1097-1113.

Yilmaz, O., Gülsün, B., Güneri, A. F., Özgürler, Ş., Endüstri, B. Y., \& Besiktas, M. B. (2011). Supplier selection of a textile company with ANP. In Int. Research. Conf. Trends in Development of Machinery and Associated Technology (Vol. 15, pp. 257-60).

Zavadskas, E. K., Turskis, Z., \& Antucheviciene, J. (2015). Selecting a contractor by using a novel method for multiple attribute analysis: Weighted Aggregated Sum Product Assessment with grey values (WASPAS-G). Studies in Informatics and Control, 24(2), 141-150.

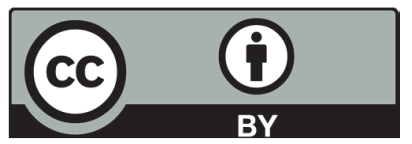

(C) 2019 by the authors; licensee Growing Science, Canada. This is an open access article distributed under the terms and conditions of the Creative Commons Attribution (CC-BY) license (http://creativecommons.org/licenses/by/4.0/). 